\title{
Ruch ludowy w Drugiej Rzeczypospolitej na kartach wybranych szkolnych podręczników do nauczania historii. Casus opracowań dla klas pierwszych szkół ponadgimnazjalnych
}

Peasant movement in the Second Republic of Poland on the pages of selected school history textbooks. A case of studies for the first grades of upper secondary schools

W 2020 r. odbyły się, skromniejsze niż zakładano ze względu na pandemię COVID-19, obchody I0o. rocznicy bitwy warszawskiej, która jako jedno z niewielu wydarzeń zapisała się nie tylko w historii Polski, ale także całego kontynentu europejskiego. Bitwa na przedpolach polskiej stolicy obecna jest nie tylko na kartach naukowych prac historycznych, ale także w kulturze i sztuce. Współcześnie za sprawą patriotycznych koszulek, opraw stadionowych, murali, gier komputerowych oraz możliwości, które stwarza Internet, i wielu innych form wyrazu, na których wymienienie brakuje tu miejsca, jest również obecna w przestrzeni publicznej'. Ta sytuacja to efekt przemian, które dokonały się w 1989 r., umożliwiając zarówno formalną, czyli szkolną, jak nieformalną edukację polskiego społeczeństwa w kwestii wydarzeń związanych z wojną polsko-sowiecką i jej najbardziej spektakularnym aktem, czyli wspomnianą bitwą warszawską z sierpnia $1920 \mathrm{r}$. W tym miejscu ktoś mógłby zapytać, jaki związek mają przywołane tu informacje z tematem prezentowanego artykułu. Powodów jest kilka, ale dwa są podstawowe. Po pierwsze, wspomniany wymiar rocznicowy - 1920-2020. Po drugie, w wydarzeniach z $1920 \mathrm{r}$. istotną rolę odegrało polskie chłopstwo,

1 Na temat obecności i form wyrazu wydarzeń i postaci z przeszłości we współczesnym świecie zob.: Historia w przestrzeni publicznej, pod red. J. Wojdon, Warszawa 2018. 
z Wincentym Witosem na czele, stając do walki z bolszewicką próbą podbicia Polski, a którego wysiłku niestety zbyt wiele osób w naszym kraju nie jest świadomych. Niestety ten ważny wątek polskiej historii nie jest wyjątkiem, a postępujący w XX i na początku XXI w. proces urbanizacji sprawił, że na historię polskiej wsi, w tym roli jaką odegrali w niej broniący jej interesów politycy, nie poświęca się zbyt wiele uwagi. I choć podejmowane są działania, które ten stan mają zmienić - tu wymienić można choćby dorobek Muzeum Historii Polskiego Ruchu Ludowego w Warszawie, publikacje historyków i politologów zajmujących się ruchem ludowym z Uniwersytetu Marii Curie-Skłodowskiej w Lublinie czy też rolę takich czasopism jak „Zeszyty Wiejskie” wydawane na Uniwersytecie Łódzkim - to wciąż są to kwestie, o których wiedza przeciętnego „Kowalskiego” jest de facto znikoma. Prezentowany artykuł stanu tego zapewne nie zmieni, ale może pomóc w zrozumieniu jego przyczyn, gdyż odwołuje się do edukacji formalnej, popularnie nazywanej też szkolną, która, jak wiadomo, jest powszechna i obowiązkowa.

Zadanie, które postawił sobie autor tekstu, a sprowadzające się do analizy obrazu ruchu ludowego w Drugiej Rzeczypospolitej na kartach współczesnych szkolnych podręczników do nauczania historii, zbiegło się w czasie $\mathrm{z}$ bezprecedensowym w najnowszej historii „zamknięciem” nie tylko naszego kraju, ale de facto większości państw świata w wyniku pandemii SARS-CoV-2, popularnie nazywanej koronawirusem. Nastąpiło to jednak w dobie elektronicznych kanałów komunikacji, a przede wszystkim Internetu, przez co nie doszło do całkowitego zablokowania międzyludzkich kontaktów, w tym procesu edukacji młodzieży oraz studentów. Aż trudno sobie wyobrazić, jakie byłyby skutki, gdyby taka sytuacja jak obecnie, zaistniała niespełna dwadzieścia lat temu, czyli na początku trzeciego tysiąclecia. A tak, choć zamknięci na kilka tygodni we własnych domach ${ }^{2}$ mogliśmy, a piszę to jako nauczyciel historii w liceum i wykładowca akademicki, niemal natychmiast rozpocząć tzw. zdalne nauczanie, wykorzystując w tym celu pocztę elektroniczną oraz różnego rodzaju aplikacje umożliwiające nauczanie w czasie rzeczywistym i to w bezpośrednim głosowym, jak i wzrokowym kontakcie. I choć to tylko namiastka bezpośredniego kontaktu, to jednak okazała się niezwykle ważna i w większości przypadków skuteczna. Wspominam o tym wszystkim, gdyż w prezentowanym artykule będzie, jak wskazuje to już sam tytuł, mowa o szkolnej edukacji historycznej w kontekście znaczenia ruchu ludowego. Jego celem nie będzie jednak analiza obrazu czołowych działaczy i partii chłopskich w Drugiej 
Rzeczypospolitej w cyfrowej przestrzeni Internetu, choć i tu materiał do badania jest już bogaty i interesujący, ale w bardziej tradycyjnych, choć także dostępnych już on-line, np. w wersji PDF podręcznikach szkolnych do nauczania historii, które uczniowie mieli w domach podczas pandemii zakaźnej choroby COVID-19 wywołanej przez koronawirusa SARS-CoV-2.

Mam świadomość, że u wielu osób już samo hasło „podręcznik szkolny” wywołuje przysłowiowe ciarki na plecach, wszak nie po to przez kilkanaście lat chodzili do szkoły, aby teraz za sprawą wspomnienia o podręcznikach do niej wracać. No może do towarzyskich spotkań z czasów szkolnych i rozmów tak, ale już do lektury książek, które nosiło się w plecaku i najczęściej otwierało na dłużej przed sprawdzianami - już niekoniecznie. I trudno się temu podejściu dziwić. $Z$ drugiej jednak strony, książek tych nie wolno lekceważyć z bardzo prostego powodu. Otóż w przypadku wielu osób były i są pierwszą, ale jednocześnie także ostatnią książką o historii, z którą mieli kontakt. A to z kolei sprawia, że to, co w niej przeczytali i zobaczyli, a zostało wzbogacone, choć nie zawsze, opowiadaniem lub wykładem nauczyciela, często decyduje o tym, co wiedzą lub czego nie wiedzą z kanonu wiedzy szkolnej, w tym historycznej. W tym miejscu uspokajam, że do innych szkolnych przedmiotów nie będziemy się odwoływać, gdyż po pierwsze nie pasowałoby to do formatu czasopisma, jakim są „Zeszyty Wiejskie”. Po drugie, czytelnicy mogliby tego nie wytrzymać, gdyż odwołanie do szkolnego przedmiotu, jak i wspomnianych podręczników, jest dla wielu z nich już wystarczająco traumatycznym doświadczeniem. Dlatego koncentrujemy się na Historii, która nauczana od klasy czwartej szkoły podstawowej, jeszcze kilka lat temu była łączona z elementami Wiedzy o spoteczeństwie. W tym miejscu przypomnijmy, że zdaniem części historyków oraz opinii publicznej w Polsce na przełomie pierwszej i drugiej dekady XXI w. edukacja historyczna ${ }^{3}$ została $\mathrm{w}$ naszym kraju w pewnym stopniu zmarginalizowana ${ }^{4}$. Stało się tak pomimo niezaprzeczalnie istotnej roli szkolnej

3 Zob. Rozporządzenie MEN z dnia 23 grudnia $2008 \mathrm{r}$. w sprawie podstawy programowej wychowania przedszkolnego oraz kształcenia ogólnego w poszczególnych typach szkól, Dziennik Ustaw Rzeczypospolitej Polskiej (dalej: Dz.U.) 2009, nr 4, poz. 17. Dostępny w Internecie: http://prawo.sejm.gov.pl/isap.nsf/download.xsp/ WDU20090040017/O/D20090017.pdf (dostęp: 24 czerwca 2020) oraz Rozporządzenie MEN z dnia 27 sierpnia 2008 r. w sprawie podstawy programowej wychowania przedszkolnego oraz kształcenia ogólnego w poszczególnych typach szkół, Dz.U. 20I2, poz. 977. Dostępny w Internecie: http://prawo.sejm.gov.pl/isap.nsf/download.xsp/ WDU20120000977/O/D20120977.pdf (dostęp: 24 czerwca 2020).

4 W gronie historyków, którzy już na przełomie 2008 i 2009 r., oprotestowali niektóre z proponowanych uregulowań, był wykładowca Uniwersytetu Jagiellońskiego i jednocześnie redaktor pisma „Arcana” Andrzej Nowak. Zob. A. Nowak, Prawdziwy koniec 
Historii w kształtowaniu nie tylko wiedzy i umiejętności, ale także postaw oraz systemu wartości młodych ludzi. W tym miejscu przypomnijmy, że od września 2012 r. uczniowie, którzy po ukończeniu trzeciej klasy gimnazjum rozpoczęli naukę w szkołach ponadgimnazjalnych, Historię, bez łączenia z Wiedzqo spoteczeństwie, jako przedmiot obowiązkowy mieli tylko przez jeden rok nauczania. W zdecydowanej większości przypadków przedmiot ten był realizowany w klasach pierwszych. Od klasy drugiej liceum i technikum tylko uczniowie, którzy wybrali Historię jako tzw. rozszerzenie, tj. przedmiot, który jako dodatkowy zdawali następnie na maturze, realizowali w wymiarze 240 godzin w cyklu 2 - lub 3-letnim. Pozostali, których była zdecydowana większość, gdyż wybrali rozszerzenia z zakresu nauk matematycznych i przyrodniczych, przez dwa lata (szkolne), realizowali (definitywny koniec tego cyklu nastąpi w czerwcu 2023 r.) - modułowo przedmiot Historia i spoteczeństwo. Dziedzictwo epok w wymiarze dwóch godzin tygodniowo, tj. I20 godzin w cyklu dwuletnim ${ }^{5}$. W naszej analizie nie będziemy jednak zajmować się szerzej tym przedmiotem, gdyż w podstawie programowej określającej wymagania szczegółowe przewidziano tylko w jednym, choć obligatoryjnym module, który zatytułowano Ojczysty Panteon i ojczyste spory, ogólny zapis mówiący o charakterystyce sporów o kształt Polski w Xx wieku oraz sylwetkach czołowych uczestników tych wydarzeń. Z kolei w wymaganiach szczegółowych dla Historii, we wspomnianych klasach pierwszych mamy już znacznie bardziej szczegółowo określone Treści nauczania - wymagania szczegótowe, które zwracaja uwage na szereg ważnych elementów życia spotecznego międzywojennej Pol$s k i^{6}$. W tym miejscu należy zaznaczyć, że w latach 2012-2020 uczniowie klas pierwszych (po gimnazjum) mieli do dyspozycji dwie godziny lekcyjne Historii tygodniowo (6o godzin w roku szkolnym), na obligatoryjną realizację materiału z historii Polski i powszechnej obejmującego okres od

historii. Dostępny w Internecie: http://www.rp.pl/artykul/23581r.html?p=3 (dostęp: 24 czerwca 2020).

5 Wspomniane wątki to kolejno: „Europa i świat”, „Język, komunikacja i media”; „Kobieta, mężczyzna, rodzina”; „Nauka”; „Swojskość i obcość”; „Gospodarka”; „Rządzący i rządzeni”; „Wojna i wojskowość”; „Ojczysty Panteon i ojczyste spory”. Więcej na temat wspomnianego przedmiotu zob.: „Historia i spoteczeństwo. Dziedzictwo epok”. Edukacja historyczna w szkole ponadgimnazjalnej po 2013 roku, red. nauk. M. Fic, Katowice-Bielsko-Biała 2012.

6 Rozporządzenie MEN z dnia 27 sierpnia 2008 r. w sprawie podstawy programowej wychowania przedszkolnego oraz kształcenia ogólnego w poszczególnych typach szkół, Dz.U. 20I2, poz.977, s. 137. Dostępne w Internecie: http://prawo.sejm.gov.pl/isap.nsf/ download.xsp/WDU20120000977/O/D20120977.pdf (dostęp: 24 czerwca 2020). 
końca I9I $8 \mathrm{r}$. do początków XXI stulecia ${ }^{7}$. W oparciu o wspomniany dokument zatwierdzenie i dopuszczenie do użytku szkolnego przez Ministerstwo Edukacji Narodowej ${ }^{8}$. Opisany powyżej stan prawny, począwszy od 2017 r. uległ zmianie, ale na jego efekty przyjdzie nam jeszcze poczekać, gdyż uczniowie nowego czteroletniego liceum i pięcioletniego technikum naukę z pełnym kursem historii rozpoczęli dopiero we wrześniu 2019 r., co oznacza, że treści dotyczące historii XX w. pierwszy rocznik nowego czteroletniego liceum oraz pięcioletniego technikum będzie realizować najwcześniej w drugim semestrze roku szkolnego 202I/2022.

Zanim przejdziemy do głównej części artykułu, nieco uwagi warto poświęcić samym szkolnym podręcznikom do nauczania historii, które do tej pory nie były na kartach „Zeszytów Wiejskich” szerzej analizowane, ani też nie stanowiły podstawy źródłowej któregokolwiek z artykułów. I tak badania prowadzone w wielu europejskich krajach pokazują, że klasyczne papierowe podręczniki historii wciąż stanowią podstawowe źródło uczniowskiej wiedzy o przeszłości ${ }^{9}$. Dzieje się tak pomimo systematycznie zwiększających się możliwości korzystania przez uczniów z pozaszkolnych źródeł informacji, wśród których w ostatnich latach szczególne miejsce

7 W tym miejscu warto przypomnieć, że od 2009 r. uczniowie w trzyletnich gimnazjach edukację historyczną kończyli na roku 1918, a nie tak jak było to w poprzednich dziesięciu latach (1999-2009), gdy realizowali pełny kurs obejmujący wydarzenia rozgrywające się niemal do końca Xx stulecia.

8 Wykaz podręczników wraz z listą rzeczoznawców ministerialnych zob. na stronie Ministerstwa Edukacji Narodowej: http://www.men.gov.pl/podreczniki/wykaz_dopuszczone_listar.php (dostęp: 24 czerwca 2020). A są to kolejno: S. Roszak, J. Kłaczkow, Poznaćprzesztość. WiekXX. Podręcznik do historii dla szkót ponadgimnazjalnych. Zakres podstawowy. Klasa I, Wydawnictwo Nowa Era, Warszawa 2012; R. Dolecki, K. Gutowski, J. Smoleński, Po prostu historia. Zakres podstawowy. Podręcznik do liceum i technikum, Wydawnictwa Szkolne i Pedagogiczne, Warszawa 2or2; B. Burda, B. Halczak, R.M. Józefiak, A. Roszak, M.Szymczak, Historia najnowsza. Podręcznik dla szkót ponadgimnazjalnych. Zakres podstawowy, Wydawnictwo Pedagogiczne Operon, Gdynia 2012; S.Zając, Teraz historia. Podręcznik dla szkoty ponadgimnazjalnej. Zakres podstawowy, sop Oświatowiec, Toruń 20I2; Z.T. Kozłowska, I. Unger, S.Zając, Historia. Poznajemy przesztość. Dzieje najnowsze. Szkota ponadgimnazjalna. Zakres podstawowy, soP Oświatowiec, Toruń 2012; D. Stola, Historia. Wiek Xx. Podręcznik. Szkoty ponadgimnazjalne. Zakres podstawowy, Wydawnictwo Szkolne PWN, Warszawa 20I2; J. Ustrzycki, Historia. Zakrespodstawowy. Podręcznik dla szkótponadgimnazjalnych, Wydawnictwo Pedagogiczne Operon, Gdynia 2or2; A. Brzozowski, G. Szczepański, Ku wspótczesności. Dzieje najnowsze IgI8-2006. Podręcznik do historii dla klasy I liceum i technikum - zakres podstawowy, Wydawnictwo Piotra Marciszuka Stentor, Warszawa 2012.

9 M. Bieniek, Podręcznik szkolny historii, [w:] Wspótczesna dydaktyka historii. Zarys encyklopedyczny dla nauczycieli i studentów, red. J. Maternicki, Warszawa 2004, s. 266; tejże, Dydaktyka historii, Olsztyn 2009, s. 72; E. Chorąży, D. Konieczka-Śliwińska, S. Roszak, Edukacja historyczna w szkole. Teoria i praktyka, Warszawa 2008, s. 162. 
zajmuje Internet. Należy jednak pamiętać, iż w natłoku błyskawicznie dostarczanych uczniom informacji to właśnie podręcznik zawierający uporządkowaną i zweryfikowaną wiedzę stanowi niezmiennie najważniejszy punkt odniesienia. Nie bez znaczenia pozostaje w tym kontekście fakt, iż konstrukcja współczesnych podręczników, zawierających obok tekstu autorskiego, tekstów uzupełniających, ikonografii historycznej i środków kartograficznych, także szereg nowinek technicznych, w tym płyty z materiałami multimedialnymi, odsyłacze do stron www, a przede wszystkim rozbudowane bloki problemowe oparte na licznych pytaniach i zagadnieniach do przedyskutowania, czyni z nich system środków dydaktycznych, który niewiele ma wspólnego ze swoim pierwowzorem. W parze z tymi zmianami dokonało się - jak podkreślał Alojzy Zielecki - „[...] przeniesienie akcentów dydaktycznych z gotowych szkolnych narracji historycznych - najczęściej podręcznikowych - na tworzenie narracji historycznych przez uczniów na podstawie dobranych źródeł i opracowań"10. W ten sposób uczeń nabiera umiejętności wydobywania ze źródeł podstawowych informacji, oddzielania od nich interpretacji i perswazji oraz przyjmowania z opracowań faktów i struktur narracyjnych.

Sięgając w zamierzchłą przeszłość, warto przypomnieć, że podręcznik uznaje się za najstarszy środek dydaktyczny stosowany w edukacji historycznej. Pierwowzorem współczesnych podręczników były uczniowskie notatki, w których utrwalane były treści przekazywane przez nauczycieli. Ich zadaniem było przygotowanie przed zajęciami wypisów z dzieł historycznych i filozoficznych, które następnie dyktowali podczas zajęć. Niektóre z tych nauczycielskich notatek trafiały następnie bezpośrednio do uczniów. Taka forma pracy pojawiła się już w starożytności, a na dobre utrwaliła w średniowieczu. Prawdziwą rewolucję w odniesieniu do podręczników spowodował wynalazek druku. To właśnie dzięki niemu pojawiły się pierwsze książki, których celem była pomoc w przyswajaniu przez uczniów wiadomości z historii. Z uwagi na fakt, iż wiadomości te uczniowie musieli często odczytywać, książki trzymali w zasięgu ręki, najczęściej „pod ręką”. Stąd też wywiedziona została stosowana także współcześnie nazwa - „podręcznik”. Na polskim gruncie pierwsze podręczniki pojawiły się w XVII stuleciu. Ich rolę w edukacji historycznej w drugiej połowie XVIII w. znacząco podniosła Komisja Edukacji Narodowej" ${ }^{1 "}$ Aktualny kształt podręczników szkolnych ma jednak stosunkowo krótką historię. Decyduje o tym fakt, iż pierwsze

10 A.Zielecki, Wprowadzenie do dydaktyki historii, Kraków 2007, s. 83.

11 M. Bieniek, Obudowa dydaktyczna polskich podręczników historii 1795-1914, Olsztyn 2001, s. 32-43; J. Maternicki, Dydaktyka historii w Polsce 1773-1918, Warszawa 1974, s. 28. 
opracowania tego typu zawierały tylko i wyłącznie tekst autorski, przez co nie były zaopatrzone w mapki, ilustracje, tabele czy zestawy specjalnych ćwiczeń dla uczniów. Pod koniec xx wieku podręczniki przeszły rewolucyjne zmiany, które uatrakcyjniły ich szatę graficzną oraz wymusiły wprowadzenie zadań, nad którymi uczniowie mają najczęściej obowiązek pracować samodzielnie. Jest to istotna zmiana wymuszona potrzebą poprawy efektów kształcenia, które nastawione są współcześnie na wyrabianie i doskonalenie umiejętności, a nie tylko przyswajanie wiedzy ${ }^{12}$. Nad merytorycznym poziomem podręczników kontrolę sprawuje Ministerstwo Edukacji Narodowej ${ }^{13}$. Z kolei za ich wnikliwą analizę oraz zgłaszanie propozycji nowych rozwiązań metodycznych odpowiadają dydaktycy historii i nauczyciele.

Od wielu lat prowadzone są prace nad nowymi rozwiązaniami, które dostosują podręczniki do współczesnych i przyszłych potrzeb edukacyjnych. Stan badań na koniec pierwszej dekady XXI w. przedstawili w tym kontekście autorzy bardzo dobrze przyjętego przez nauczycieli historii opracowania Edukacja historyczna w szkole ${ }^{14}$. Sygnalizując tu tylko niektóre przykłady potwierdzające poszukiwania rozwiązań optymalnych w zakresie interesującego nas środka dydaktycznego, warto zastanowić się również nad tym, czy inne media zwłaszcza o charakterze audiowizualnym, nadmiernie nie ograniczają roli podręcznika. Zakładamy, że rola podręcznika w epoce pedagogiki posługującej się nowoczesnymi środkami dydaktycznymi, a tu technologia informatyczna, a w szczególności Internet dokonały prawdziwej rewolucji, paradoksalnie jednak nie zmniejsza się w znaczący sposób, choć trudno powiedzieć, że ulega wzmocnieniu, jak było to ćwierć wieku temu ${ }^{15}$. Współczesna technika i środki masowego komunikowania stworzyły wiele źródeł informacji wykorzystywanych zarówno w szkole, jak również w systemie oświaty równoległej. Jest rzeczą oczywistą, że te środki oddziaływają na ucznia wspólnie, ale nie w ten sam sposób i nie z tymi samymi efektami. Zasadnicza różnica leży w przedziale zadań, przy czym

12 M. Bieniek, Dydaktyka historii..., s. 73, 83-85.

13 Od I stycznia 2021 r. w miejsce MEN istnieje Ministerstwo Edukacji i Nauki.

14 E. Chorąży, D. Konieczka-Śliwińska, S. Roszak, dz. cyt., s. I62-I7ı.

15 Historycy, dydaktycy historii i nauczyciele przedmiotu zwracali na to uwagę już na początku XXI w. Zob.: K. Jurek, Internet w pracy nauczyciela historii, „Wiadomości Historyczne" 2001, nr 4, s. 212-219; S. Batok, Internetowe strony historyczne, w edukacji medialnej, [w:] Multimedia w edukacji historycznej ispotecznej, red. J. Rulka, B. Tarnowska, Bydgoszcz 2002, s. I13-131; J. Wojdon, Internet na lekcjach historii, „Wiadomości Historyczne" 2002, nr 2, s. 77-79; Z. Osiński, Technologia informacyjna środkiem dydaktycznym w edukacji historycznej, [w:] Edukacja historyczna i obywatelska w szkolnictwie ponadgimnazjalnym, red. G. Pańko, J. Wojdon, Toruń 2003, s. 462-476. 
każdy ze środków nauczania i każde pozaszkolne źródło informacji stanowi jeden z czynników. Wśród nich podręcznikowi przypada rola szczególna.

Wynika to między innymi z faktu, że chociaż pozaszkolne źródła wiedzy historycznej są bardziej zróżnicowane i przy tym atrakcyjniejsze dla odbiorców, to jednak w porównaniu z nimi podręcznik przekazuje informacje w formie uporządkowanej, systematycznej, stając się dzięki temu swoistym punktem odniesienia dla informacji pochodzących z różnych mediów. Dlatego współczesna dydaktyka uznaje wiodącą rolę podręcznika w systemie wszystkich środków dydaktycznych. Winien to być jednak podręcznik obudowany w sposób planowy i celowy pozapodręcznikowymi środkami dydaktycznymi o zróżnicowanym charakterze. Aktualnie, tj. pod koniec drugiej dekady XXI w. stało się to wręcz standardem, w czym ogromna zasługa prywatnych wydawnictw edukacyjnych, które rywalizując o uznanie nauczycieli i uczniów, na przestrzeni zaledwie kilkunastu ostatnich lat, w sposób wręcz trudny do wyobrażenia pod koniec ubiegłego stulecia, zrewolucjonizowały obudowę standardowych papierowych podręczników. W efekcie uczniowie mogą znacząco wzbogacić wiedzę oraz udoskonalić umiejętności, które umożliwia tradycyjny podręcznik, wykorzystując ofertę zamieszczoną jeszcze kilka lat temu na płytach CD i DVD, a obecnie za pośrednictwem materiałów zamieszczonych na stronach internetowych wydawnictw. Niezależnie od tych przemian oczekiwania dydaktyków, nauczycieli, a przede wszystkim uczniów są niezmienne, co oznacza, że podręcznik nie tylko będzie wyposażał uczniów w wiedzę, ale także pobudzał ich dociekliwość oraz uczył samodzielnego stawiania i rozwiązywania problemów. Aby podręcznik mógł spełnić to zadanie, musi być księgą otwartą, pozostawiającą możliwie szeroki margines dla wysiłku myślowego.

Po tym dłuższym fragmencie tekstu, który poświęciliśmy podręcznikom, najwyższy czas przejść do analizy ich zawartości w kontekście obecności informacji dotyczących ruchu ludowego. Ruchu, o którym uczniowie klas pierwszych mieli okazję dowiedzieć się po raz pierwszy na lekcjach historii już w klasie trzeciej gimnazjum, gdyż to właśnie w programie nauczania na tym poziomie znalazły się zapisy, które zmusiły nie tylko nauczycieli historii, ale i autorów podręczników do omówienia najważniejszych informacji związanych z jego powstaniem, czołowymi ugrupowaniami i działaczami politycznymi. Zwracam uwagę na ten fakt, gdyż pozwala on na kolejnym etapie edukacyjnym, czyli interesującym nas tu IV - odpowiadającym szkołom ponadgimnazjalnym, obecnym ponadpodstawowym - odwołać się do tzw. wiedzy przedlekcyjnej uczniów. A tu, jak pokazuje analiza jednego z najpopularniejszych podręczników 
do klasy trzeciej gimnazjum, który w $201 \mathrm{r}$ r. przygotowało Wydawnictwo Nowa Era, można było znaleźć informacje mówiące o tym, że ruch ludowy powstał w zaborze austriackim pod koniec XIX w. W dalszej części uczniowie mogli przeczytać o działalności Stanisława Stojałowskiego, Marii i Bolesława Wysłouchów i Franciszka Stefczyka oraz motywach, które legły u podłoża ich działalności, w tym przede wszystkim bardzo trudnej sytuacji na galicyjskiej wsi. Wreszcie o powstaniu pierwszej partii chłopskiej - Stronnictwa Ludowego - na wiecu w Rzeszowie 28 II 1895 r. A także o przekształceniu tej partii w 1903 r. w Polskie Stronnictwo Ludowe i rozłamu, do którego w nim doszło w I9I3 r., w wyniku którego wyodrębniło się skupiające biedniejszych chłopów PSL-Lewica oraz kierowany przez Wincentego Witosa - PSL „Piast” ${ }^{16}$. Z przytoczonych tu informacji wynika, że przysłowiowy grunt pod wzbogacenie uczniowskiej wiedzy o jednym z najważniejszych nurtów politycznych w historii narodu i państwa polskiego został położony.

Życie polityczne Drugiej Rzeczypospolitej na kartach szkolnych podręczników, podobnie z resztą jak i w naukowych syntezach okresu międzywojennego w odniesieniu do Polski, zdominowały, i to w podanej tu kolejności dwie postaci - Józef Piłsudski i Roman Dmowski". Postacią, która lokuje się jednak tuż za nimi jest najważniejszy, co zgodnie podkreślają wszyscy autorzy analizowanych podręczników, polityk ludowy, określany też mianem chłopskiego lidera - Wincenty Witos ${ }^{18}$. O takiej ocenie decyduje kilka czynników, a wśród nich między innymi fakt, iż W. Witos jest pierwszym z polityków ludowych, o którym uczniowie mogą dowiedzieć się z kart analizowanych podręczników. Otóż w tematach, które poświęcone zostały odrodzeniu/odbudowie państwa polskiego w 1918 r. podana została informacja - o utworzeniu w Krakowie 28 października Polskiej Komisji

16 Te pierwsze w szkolnej edukacji historycznej uczniów informacje dotyczące powstania i działalności polskiego ruchu ludowego, autorzy podręcznika, zakończyli stwierdzeniem, że poza Galicją nie rozwinął się on na znaczącą skalę w żadnym z zaborów (S. Roszak, A. Łaszkiewicz, Śladami przesztości. Podręcznik do historii dla klasy trzeciej gimnazjum, Wydawnictwo Nowa Era, Warszawa 2011, s. 232).

17 Wprost można takie stwierdzenia przeczytać w kilku opracowaniach. Zob.: B. Burda, B. Halczak, R.M.Józefiak, A. Roszak, M. Szymczak, dz. cyt., s. 72; R. Dolecki, K. Gutowski, J.Smoleński, dz. cyt., s. 32 .

18 W jednym z opracowań, po dłuższym fragmencie, który autorzy poświęcili Piłsudskiemu i Dmowskiemu, czytamy, że „W budowie państwa bardzo zasłużyli się także: przywódcy ruchu ludowego - Wincenty Witos i Maciej Rataj, socjalista Ignacy Daszyński oraz działacz chrześcijańskiej demokracji - Wojciech Korfanty" (Z.T. Kozłowska, I. Unger, S.Zając, dz. cyt., s. 57). 
Likwidacyjnej, na czele której stał nie kto inny tylko W. Witos ${ }^{19}$. Inni zaznaczyli, że PSL „Piast” i PSL „Wyzwolenie” weszły jako partie w jego skład ${ }^{20}$.

Do lidera PSL „Piast” przyjdzie nam jeszcze powrócić, ale zachowując układ chronologiczny analizowanych i omawianych zagadnień związanych w ruchem ludowym w Drugiej Rzeczypospolitej, musimy przejść do wydarzeń z 1919 r. Decyduje o tym fakt, iż 26 stycznia tegoż roku odbyły się pierwsze w historii międzywojennej Polski wybory. Wyłoniono wówczas większą część składu jednoizbowego parlamentu, który do historii przeszedł pod nazwą Sejmu Ustawodawczego. W podręcznikach informacja na ten temat została obudowana (ale nie w przypadku wszystkich opracowań) szczegółowymi wynikami uzyskanymi przez poszczególne partie. W efekcie część uczniów mogła się dowiedzieć, że PSL „Piast” uzyskał 35 mandatów, a PSL „Wyzwolenie" $-44^{21}$. W innym opracowaniu na wykresie kołowym podano, że „Piast” uzyskał poparcie na poziomie $13,4 \%$, a o „Wyzwoleniu” poinformowano tylko, że liczone razem z PPS uzyskało $31,1 \%{ }^{22}$. Przy tej okazji uczniowie mogli po raz pierwszy przeczytać, że partia, której liderem był W. Witos należała do tzw. ugrupowań centrowych, choć część autorów określiła ją mianem partii prawicowej. Z kolei przy „Wyzwoleniu” pojawiły się informacje, że była to partia o obliczu lewicowym ${ }^{23}$. W części opracowań odnotowano tylko, że „Piast” i „Wyzwolenie” weszły do Sejmu Ustawodawczego ${ }^{24}$.

Podobna sytuacja, tzn. podanie wyników wyborów z podziałem na poszczególne ugrupowania, co pozwoliło nie tylko na poznanie układu sił w parlamencie, ale także służyło utrwaleniu nazw ugrupowań ludowych, dotyczy, ale ponownie tylko w części opracowań, wyników do Sejmu i Senatu z listopada $1922 \mathrm{r}$. W kilku opracowaniach wykorzystano do tego celu np. wykresy kołowe lub słupkowe, na których uczniowie mogli przeczytać, że PSL „Piast” zdobył I6\% miejsc w Sejmie, PSL „Wyzwolenie” - II\%, a Stronnictwo Chłopskie wspólnie z PPS „Lewicą” - I\% ${ }^{25}$. Ten sam rodzaj przedstawienia wyników, czyli wykres kołowy, wykorzystali autorzy podręcznika wydanego przez Nową Erę, tyle tylko, że podali podział mandatów

\footnotetext{
19 S. Roszak, J. Kłaczkow, dz. cyt., s. 66; R. Dolecki, K. Gutowski, J.Smoleński, dz. cyt., s. 29; A. Brzozowski, G. Szczepański, dz. cyt., s. I6; J. Ustrzycki, dz. cyt., s. I8; D. Stola, 
w Sejmie, z którego uczniowie mogli się dowiedzieć, że PSL „Piast” uzyskał ich 70, PSL „Wyzwolenie” - 48, a Chłopskie Stronnictwo Radykalne i Komunistyczny Związek Proletariatu Miast i Wsi $-6^{26}$. W innych podano tylko, że PSL „Piast” był najsilniejszym ugrupowaniem centrowym, ale jednocześnie bardzo ważnym dla układu sił w parlamencie, gdyż to od niego „[... mógł zależeć charakter nowego rządu, a nawet osoba prezydenta” ${ }^{27}$, o czym będzie jeszcze okazja wspomnieć.

W związku z tym, że celem artykułu jest analiza działalności ruchu ludowego, a nie sytuacji na polskiej wsi, w tym miejscu odnotujmy tylko, że we wszystkich $\mathrm{z}$ analizowanych podręczników przedstawione zostały bardzo tragiczne dla polskiego rolnictwa i położenia ludności wiejskiej konsekwencje Wielkiej Wojny ${ }^{28}$. W kolejnych rozdziałach tych opracowań omówiono strukturę społeczną Drugiej Rzeczypospolitej, zaznaczając, że około 70\% populacji mieszkało na wsi, a między 50 a $53 \%$ utrzymywało się z pracy w rolnictwie ${ }^{29}$. Zwracam uwagę na ten fakt, gdyż często autorzy podręczników, „rozbijając” informacje na ten temat sprawiają, że uczniowie, jeśli nie wyjaśni im tego nauczyciel podczas lekcji, mają problem ze zrozumieniem dużego poparcia, jakie partie ludowe uzyskiwały w wyborach parlamentarnych w okresie międzywojennym, a w szczególności w latach I919 i 1922.

W tym miejscu należy zwrócić uwagę, że w trzech spośród ośmiu analizowanych książek ich autorzy zdecydowali się na opracowanie specjalnych zestawień tabelarycznych, w których w przejrzysty sposób przedstawili główne nurty polityczne Drugiej Rzeczypospolitej ${ }^{30}$. W dwóch kolejnych kwestie te ujęto na infografice ${ }^{31}$ oraz schemacie, w którym przy użyciu kolorowej czcionki zilustrowano ewolucję polskich partii politycznych, w tym tych, które tworzyły ruch ludowy ${ }^{32}$. W jednym opracowaniu poświęcono im dłuższy akapit rozdziału odnoszącego się do okresu rządów

26 S. Roszak, J. Kłaczkow, dz. cyt., s. 88.

27 J. Ustrzycki, dz. cyt., s. 52; R. Dolecki, K. Gutowski, J. Smoleński, dz. cyt., s. 49. Zob. także: tamże, s. 52 .

28 Więcej na ten temat zob.: A. Suchoński, B. Kubis, A. Gołębiowska, M. Białokur, Polski rok I9I 8 w podręcznikach do nauczania historii i literaturze dokumentu osobistego, Opole 2018 , s. II7-I20; A. Suchoński, B. Kubis, A. Gołębiowska, M. Białokur, Polski rok IgIo w podręcznikach do nauczania historii i literaturze dokumentu osobistego, Opole 2019, s. 69-93.

29 Przykładowo: J. Ustrzycki, dz. cyt., s. 4I; S. Zając, dz. cyt., s. 48.

30 R. Dolecki, K. Gutowski, J. Smoleński, dz. cyt., s. I49; D. Stola, dz. cyt., s. 46; A. Brzozowski, G. Szczepański, dz. cyt., s. 37 .

31 S. Roszak, J. Kłaczkow, dz. cyt., s. 88-89.

32 Z.T. Kozłowska, I. Unger, S.Zając, dz. cyt., s. 5r. 
demokratycznych w Polsce ${ }^{33}$. Dla wszystkich sił politycznych we wspomnianych tabelach zachowano ten sam układ, w którym w pierwszej kolejności podano datę utworzenia danej partii. W konsekwencji pojawiła się data powstania PSL „Piast” jako przełomu lat 1913/1914 oraz PSL „Wyzwolenia" - rok $1915^{34}$. W dalszej kolejności wymienieni zostali liderzy oraz najważniejsze osoby w partii. I tu w odniesieniu do „Piasta” w każdym przypadku wymieniony został W. Witos, a zaraz po nim Maciej Rataj ${ }^{35}$. Z kolei w przypadku „Wyzwolenia”- Stanisław Thugutt i Tomasz Nocznicki ${ }^{36}$. W jednym podręczniku odnotowano Stanisława Mikołajczyka ${ }^{37}$. Co ciekawe, w nielicznych podręcznikach podana została informacja, że politykiem PSL „Piast” był także Stanisław Wojciechowski, który w $1922 \mathrm{r}$. został wybrany jako drugi prezydent w historii Polski ${ }^{38}$.

Po tych podstawowych informacjach autorzy przeszli do wymienienia głównych postulatów programowych dwóch głównych partii ludowych. Aby dokładnie oddać treść, poniżej pozwolę sobie na ich przytoczenie, co umożliwi na dokonanie porównania w ujęciu trzech wspomnianych opracowań. W podręczniku Wydawnictwa Szkolnego PWN zaznaczono, że partie ludowe nie miały w Drugiej Rzeczypospolitej tak sprecyzowanej ideologii, jak np. ruch narodowy czy socjalistyczny, co ułatwiało im wchodzenie w różne koalicje. Następnie podkreślono, że reprezentowały interesy zarówno bogatszej, jak i biedniejszej warstwy chłopskiej, co powodowało, że mocno różniły się między sobą przede wszystkim stopniem radykalizmu w żądaniach reformy rolnej - „Piast” był bardziej zachowawczy, chronił własność prywatną i porządek społeczny wsi, podczas gdy „Wyzwolenie" żądało parcelacji ziemi bez odszkodowania dla obszarników i chętnie współpracowało z socjalistami, sięgając choćby po hasła antyklerykalne ${ }^{39}$. W opracowaniu Stentora w programie „Piasta” wymienione zostały kolejno: podkreślenie znaczenia chłopstwa jako najliczniejszej warstwy społecznej, obrona demokracji parlamentarnej oraz przeprowadzenie

33 S.Zając, dz. cyt., s. 52.

34 A. Brzozowski, G. Szczepański, dz. cyt., s. 37. Ponadto w jednym uwzględniono także Stronnictwo Chłopskie, które powstało w 1926 r. (R. Dolecki, K. Gutowski, J.Smoleński, dz. cyt., s. 149).

35 A. Brzozowski, G. Szczepański, dz. cyt., s. 37; D. Stola, dz. cyt., s. 46. Zob. także: Z.T. Kozłowska, I. Unger, S.Zając, dz. cyt., s. 5 I.

36 A. Brzozowski, G. Szczepański, dz. cyt., s. 37.

37 R. Dolecki, K. Gutowski, J. Smoleński, dz. cyt., s. I49.

38 J. Ustrzycki, dz. cyt., s. 53.

39 D. Stola, dz. cyt., s. 46. 
reformy rolnej. Z kolei w odniesieniu do „Wyzwolenia” powtórzono dwa pierwsze postulaty z programu „Piasta” oraz zaznaczono, że reforma rolna miała być przeprowadzona bez odszkodowania dla ziemian. Dodatkowy postulat tej partii dotyczył ograniczenia wpływów Kościoła ${ }^{40}$. Z kolei w opracowaniu WSiP charakteryzując program PSL „Piast”, podano, że chłopstwo było w nim określone jako największa siła narodu, ustrojem pożądanym - demokracja parlamentarna, reforma rolna miała być przeprowadzona za odszkodowaniem i należało dążyć do tworzenia dużych i wydajnych gospodarstw rolnych. Przy programie "Wyzwolenia” pojawiła się informacja, że jako partia skupiająca głównie ubogich chłopów walczyła o „rząd ludowy”, wzmocnienie władzy ustawodawczej - jednoizbowy parlament oraz autonomię dla mniejszości narodowych. I wreszcie odnosząc się do Stronnictwa Chłopskiego, zaznaczono, że głosiło program lewicowy, w ramach którego postulowało przeprowadzenie reformy rolnej bez odszkodowań i upaństwowienie kopaln ${ }^{41}$.

Inny układ ma informacja o ruchu ludowym zamieszczona na wspomnianej infografice w podręczniku Nowej Ery. Autorzy w jednym akapicie połączyli informacje o dwóch głównych partiach ludowych, uczniowie mogli przeczytać, że „Piast” i „Wyzwolenie” kierowały swój program do najliczniejszej wówczas grupy społecznej, jaką było chłopstwo. Głosiły hasła agrarystyczne, domagając się między innymi przeprowadzenia reformy rolnej. Ponadto zaznaczyli, że „Piast” był stronnictwem centrowym, które popierała głównie ludność byłego zaboru austriackiego, podczas gdy "Wyzwolenie" miało charakter lewicowy, a jego sympatycy zamieszkiwali głównie byłe Królestwo Polskie. W ostatnim zdaniu wykładu podali, że w I93I r. doszło do połączenia tych ugrupowań w Stronnictwo Ludowe, a głównymi działaczami całego ruchu chłopskiego byli W. Witos i M. Rataj $^{42}$. Z kolei w wykładzie Stanisława Zająca, który przygotował podręcznik dla wydawnictwa sop Oświatowiec, poza nazwą dwóch głównych partii, wskazaniem na W. Witosa jako lidera „Piasta” najwięcej miejsca zajmuje wskazanie znanych nam już różnic, które dzieliły je w kwestii sposobu i zasad, na jakich miała być przeprowadzona reforma rolna ${ }^{43}$.

Jak już wspomniano, W.Witos to postać, która spośród wszystkich polityków ruchu ludowego jest zdecydowanie najobszerniej opisana przez

\footnotetext{
40 A. Brzozowski, G. Szczepański, dz. cyt., s. 37.

41 R. Dolecki, K. Gutowski, J. Smoleński, dz. cyt., s. 149.

42 S. Roszak, J. Kłaczkow, dz. cyt., s. 88.

43 S.Zając, dz. cyt., s. 52.
} 
autorów analizowanych podręczników. Naturalnie decyduje o tym pozycja, którą zajmował nie tylko w szeregach ruchu, ale w całym polskim życiu politycznym. A tu bez wątpienia szczególną pozycję zagwarantowało mu trzykrotne pełnienie funkcji premiera polskiego rządu ${ }^{44}$. W tej sytuacji trudno się dziwić, że W. Witos obok M. Rataja jest jedynym politykiem nurtu ludowego, który ma w kilku podręcznikach osobne biogramy opatrzone zdjęciem. Ale do tej ostatniej kwestii, czyli ikonografii, która jest elementem obudowy dydaktycznej podręczników, powrócimy w ostatniej części analizy. Wracając do treści zawartej w biogramach, już na wstępie należy podkreślić, iż prawie w każdym przypadku zawierają one lata życia - I874-1945. Pozostałe informacje mają już jednak zróżnicowany charakter. I tak Dariusz Stola podkreślił, że był wybitnym przywódcą ruchu ludowego, który pochodził z ubogiej rodziny chłopskiej w Małopolsce. W dalszej części biogramu, zapewne z uwagi na fakt, iż umieścił go na stronie, na której opisał bitwę warszawską z 1920 r., przytoczył fragment jego odezwy do chłopów - „Od was, bracia włościanie, zależy, czy Polska będzie wolnym państwem ludowym, w którym lud będzie rządził i żył szczęśliwie, czy też stanie się niewolnikiem Moskwy, czy będzie się rozwijać w wolności i dobrobycie, czy też będzie zmuszona pod batem władców Rosji pracować dla najeźdźców i żywić ich krwią i znojem" ${ }^{45}$. Andrzej Brzozowski i Grzegorz Szczepański uwypuklili, że pochodził z chłopskiej rodziny z Galicji, a jako działacz ruchu ludowego był trzykrotnie premierem w latach 1920-I92I, 1923 i $1926^{46}$. Autorzy podręcznika wydanego przez WSip napisali z kolei, że był politykiem, prezesem PSL „Piast”, trzykrotnym premierem, który po zamachu majowym był w opozycji, a w latach 1933-1939 przebywał na emigracji. Z kolei po wybuchu II wojny światowej nie angażował się w działalność polityczną ${ }^{47}$. Natomiast dla Stanisława Zająca istotne było podkreślenie, że w krytycznym momencie wojny polsko-bolszewickiej pełnił funkcję premiera, a jednocześnie był krytycznie postrzegany przez część społeczeństwa za decyzję o stłumieniu strajków robotniczych w $1923 \mathrm{r}^{48}$

W tym miejscu wracamy do wspomnianego premierostwa W. Witosa, które szczególnie za pierwszym razem, tj. w latach 1920-192I było niezwykle ważne, gdyż przypadało na szczególnie burzliwy okres dziejów Drugiej

\footnotetext{
44 A. Brzozowski, G. Szczepański, dz. cyt., s. 38.

45 D. Stola, dz. cyt., s. 17.

46 A. Brzozowski, G. Szczepański, dz. cyt., s. 38.

47 R. Dolecki, K. Gutowski, J. Smoleński, dz. cyt., s. 107.

48 S.Zając, dz. cyt., s. 55 .
} 
Rzeczypospolitej. Otóż funkcję premiera W. Witos, jak zaznaczono we wszystkich opracowaniach, objąt w wyjątkowo trudnym momencie, gdy Polska stała w obliczu realnej utraty niepodległości za sprawą błyskawicznie posuwających w głąb jej terytorium wojsk bolszewickich. W dramatycznej sytuacji, po wymuszeniu przez Naczelnika Państwa Józefa Piłsudskiego dymisji rządu Władysława Grabskiego, co było, jak zaznaczono, między innymi konsekwencją jego nieudanych zdaniem Marszałka negocjacji na forum konferencji w belgijskim Spa - W. Witos otrzymał propozycję objęcia urzędu szefa Rządu Obrony Narodowej ${ }^{49}$.

Przy tej okazji jeden z autorów napisał, że I2 VIII 1920 r. na ręce W. Witosa marszałek J. Piłsudski złożył dymisję z zajmowanego stanowiska Naczelnika Państwa, który to dokument premier schował i oddał autorowi po tym, jak minęło zagrożenie. Inny za istotne uznał, aby młodzież zapamiętała, że tuż przed tą decyzją „,...] Sejm przyjął ustawę o reformie rolnej, nakazującą przydział ziemi na bardzo korzystnych warunkach w pierwszej kolejności małorolnym i bezrolnym" ${ }^{50}$, które to posunięcie miało znacząco utrudnić bolszewikom antypaństwową agitację wśród uboższych warstw chłopskich.

Kolejny raz z ruchem ludowym na kartach analizowanych podręczników uczniowie mieli okazję zetknąć się przy opisie wyborów prezydenckich z 9 XII 1922 r., które zgodnie z konstytucją uchwaloną w I7 III I92I r. - popularnie nazywaną „konstytucją marcową” - dokonało Zgromadzenie Narodowe. Ten z punktu widzenia działalności ruchu ludowego rzadko podnoszony nie tylko na gruncie edukacji szkolnej, ale w ogóle w historiografii polskiej okresu międzywojennego wątek jest bardzo interesujący, gdyż od blisko stu lat ta dramatyczna, bo zakończona po zaledwie tygodniu prezydentura Gabriela Narutowicza, w wyniku zamachu dokonanego w gmachu warszawskiej „Zachęty” przez Eligiusza Niewiadomskiego, rozpala emocje Polaków ${ }^{51}$. Wynika to z faktu, że to właśnie głosy polityków chłopskich, a przede wszystkim tych z PSL „Piast” przesądziły o wyborze kandydata zgłoszonego - nomem omen przez inną partię ludową - czyli „Wyzwolenie" 52 . Tak więc z grona analizowanych podręczników w zaledwie

49 S. Roszak, J. Kłaczkow, dz. cyt., s. 74; R. Dolecki, K. Gutowski, J. Smoleński, dz. cyt., s. 39; B. Burda, B. Halczak, R.M. Józefiak, A. Roszak, M.Szymczak, dz. cyt., s. 59; D. Stola, dz. cyt., s. 17; S. Zając, dz. cyt., s. 55 .

50 J. Ustrzycki, dz. cyt., s. 33 .

51 Więcej zob.: M.J.Nowak, Narutowicz Niewiadomski. Biografie równolegte, Warszawa 2019; M. Białokur, Gabriel Narutowicz. Biografia, Opole 2016.

52 Informację o tym, że to PSL „Wyzwolenie” zgłosiło kandydaturę G. Narutowicza znajdziemy w: B. Burda, B. Halczak, R.M. Józefiak, A. Roszak, M. Szymczak, dz. cyt., s. 76; A. Brzozowski, G. Szczepański, dz. cyt., s. 40; S. Roszak, J. Kłaczkow, dz. cyt., s. 9 I. 
kilku znalazła się informacja, że to właśnie głosy partii kierowanej przez W. Witosa, na które liczyła prawica, czyli popularna Chjena, przesądziły, że jej kandydat Maurycy Zamoyski przegrał. A wygrał je, ku niemal powszechnemu zaskoczeniu, G. Narutowicz ${ }^{53}$. Ponadto w jednym z podręczników uczniowie mogli przeczytać, że oparciem dla rządu, który po zabójstwie G. Narutowicza utworzył premier Władysław Sikorski, był obok lewicy i mniejszości białoruskiej - PSL „Piast” ${ }^{\text {. }}$.

W tym miejscu odnotujmy, że wymieniany już przez nas i jednocześnie drugi najczęściej pojawiający się w podręcznikach po W. Witosie polityk ludowy, czyli M. Rataj, ma dwa przysłowiowe „wejścia”. Pierwsze w grudniu 1922 r., gdy po zabójstwie G. Narutowicza, na mocy konstytucji z I92I r. pełni funkcję głowy państwa ${ }^{55}$. I drugie, gdy po dramatycznych wydarzeniach z 12-I5 V 1926 r. i ustąpieniu z urzędu S. Wojciechowskiego, wykorzystany zostaje ten sam zapis konstytucji i M. Rataj ponownie zostaje głową państwa ${ }^{56}$. Do przewrotu majowego jeszcze powrócimy, ale w tym miejscu zatrzymajmy się jeszcze na chwilę przy M. Rataju, gdyż w dwóch podręcznikach poświęcone zostały mu osobne biogramy opatrzone fotografią portretową. I tak w biogramie, który przygotowali autorzy podręcznika wydanego przez Operon, czytamy, że żył w latach I884-1940, był działaczem ruchu ludowego, który zajmował się publicystyką oraz pracował jako nauczyciel. Ponadto, w latach 1922-1928 był marszałkiem sejmu, przez pewien okres ministrem wyznań religijnych i oświecenia publicznego, a w latach 30. redaktorem naczelnym „Zielonego Sztandaru”, który był organem Stronnictwa Ludowego. Ostatnia informacja w przywołanym biogramie dotyczy jego uwięzienia przez Niemców podczas II wojny światowej i zamordowania koło Palmir pod Warszawą ${ }^{57}$. Bardzo podobną treść ma biogram zamieszczony w podręczniku wSiP, w którym dodatkowo podkreślono tylko, że po śmierci G. Narutowicza pełnił obowiązki prezydenta ${ }^{58}$.

Kolejna odsłona obecności ruchu ludowego w życiu politycznym Drugiej Rzeczypospolitej na kartach podręczników szkolnych dotyczy wydarzeń z roku 1923. To wówczas doszło do podpisania tzw. „paktu lanckorońskiego”,

53 D. Stola, dz. cyt., s. 46; Z.T. Kozłowska, I. Unger, S.Zając, dz. cyt., s. 8I; R. Dolecki,

K. Gutowski, J. Smoleński, dz. cyt., s. 50.

54 Z.T. Kozłowska, I. Unger, S.Zając, dz. cyt., s. 82.

55 J. Ustrzycki, dz. cyt., s. 52; Z.T. Kozłowska, I. Unger, S.Zając, dz. cyt., s. 82.

56 S. Roszak, J. Kłaczkow, dz. cyt., s. 97; J. Ustrzycki, dz. cyt., s. 95.

57 B. Burda, B. Halczak, R.M. Józefiak, A. Roszak, M. Szymczak, dz. cyt., s. 8 I.

58 R. Dolecki, K. Gutowski, J. Smoleński, dz. cyt., s. 48. 
którego efektem było powstanie tzw. pierwszego rządu Chejno-Piasta ${ }^{59}$. Informację na ten temat podała większość autorów, zaznaczając, że na czelne gabinetu stanął W. Witos ${ }^{60}$. W części opracowań zaznaczono, że rząd upadł po fali protestów, które wybuchły w listopadzie tego samego roku, a których kulminacją były dramatyczne wydarzenia w Krakowie z 6 listopada ${ }^{61}$. W tym kontekście uwagę zwraca materiał, który zamieścili autorzy podręcznika wydanego przez Stentora, którzy posłużyli się fragmentem Kalendarza historycznego. Polemicznej historii Polski, którą napisał Jerzy Łojek. W ten sposób wprowadzili na karty podręcznika źródło historiograficzne, w którym uczniowie mogli przeczytać, że zanim doszło do reformy walutowej w kraju, którą przeprowadził rząd W. Grabskiego - nastąpiły dramatyczne wydarzenia, po czym następuje opis wypadków, w wyniku których w listopadzie wybuchły strajki i doszło do walk na ulicach Krakowa, gdzie - „[...] zginęło 3 oficerów i I ułanów, rannych było ıo ułanów i 38 policjantów. Zginęło i 8 robotników" - i upadł rząd W. Witosa ${ }^{62}$.

Niestety zaledwie w dwóch $\mathrm{z}$ analizowanych podręczników odnotowano, że jeden z najbardziej znanych, z racji przeprowadzonych reform, rządów Drugiej Rzeczypospolitej, na czele którego stał W. Grabski, nie mógłby funkcjonować bez poparcia największych klubów ludowych w parlamencie ${ }^{63}$. $\mathrm{Z}$ niezrozumiałych dla autora artykułu względów przy opisie reformy rolnej,

59 A. Brzozowski, G. Szczepański, dz. cyt., s. 4I; Z.T. Kozłowska, I. Unger, S. Zając, dz. cyt., s. 82; R. Dolecki, K. Gutowski, J. Smoleński, dz. cyt., s. ı०6.

60 Jako modelową, choć nie wolną od nadinterpretacji, narrację w tej kwestii można wskazać informację zamieszczoną w podręczniku Operonu, w której czytamy: „W maju $1923 \mathrm{r}$. PSL „Piast” zawarł polityczny sojusz ze swoim niedawnym przeciwnikiem, Chrześcijańskim Związkiem Jedności Narodowej. - To trochę dziwne, gdyż strony te w listopadzie 1922 r. porozumiały się i wspólnie przegłosowały swoich marszałków w Sejmie (Rataj) i Senacie (Trąmpczyński). - Porozumienie to nazwano paktem lanckorońskim - od miejsca podpisania, czyli Lanckorony koło Krakowa. - Jest to kolejną pomyłką, gdyż w Lanckoronie faktycznie prowadzono rozmowy, ale porozumienie w wyniku, którego powstał rząd, podpisano I7 maja I923 r. w Warszawie. - Efektem było sformowanie tak zwanego rządu Chjeno-Piasta, na którego czele stanął przywódca PSL „Piast” Wincenty Witos. Potoczna nazwa rządu pochodziła od skrótu CHJN (Chrześcijańska Jedność Narodowa) oraz drugiego członu nazwy partii Witosa” (J. Ustrzycki, dz. cyt., s. 52).

61 R. Dolecki, K. Gutowski, J. Smoleński, dz. cyt., s. I33; D. Stola, dz. cyt., s. 47.

62 A. Brzozowski, G. Szczepański, dz. cyt., s. 4I.

$63 \mathrm{~W}$ podręcznikach tych napisano także, że rząd, którym kierował w $1923 \mathrm{r}$. Witos - przeprowadził wiele istotnych reform (Z.T. Kozłowska, I. Unger, S.Zając, dz. cyt., s. 82; S.Zając, dz. cyt., s. 55). Na temat wpływu partii ludowych na funkcjonowanie rządu Władysława Grabskiego zob.: H. Walczak, Drugi gabinet Wtadystawa Grabskiego In grudnia 1923 - 13 listopada 1925, [w:] Od Moraczewskiego do Sktadkowskiego. Gabinety Polski odrodzonej 1918-1939, pod red. J. Farysia, A. Wątora i H. Walczaka, Szczecin 2010, s. 155-170. 
która była jednym z najważniejszych wyzwań społeczno-gospodarczo-politycznych międzywojennej Polski, autorzy podręczników, poza nielicznymi wyjątkami, pominęli stanowisko poszczególnych ugrupowań ludowych ${ }^{64}$. Do wyjątków należą opracowania przygotowane dla Wydawnictwa Pedagogicznego Operon. Autorzy pierwszego zaznaczyli, że ideę reformy rolnej popierały zwłaszcza ugrupowania ludowe i lewicowe, które potrzebę jej przeprowadzenia tłumaczyły przede wszystkim sprawiedliwością społeczną. Podczas gdy krytycznie do reformy odnosiły się ugrupowania prawicowe, ale w dyskusji, która toczyła się w sejmie i na łamach prasy - wszystkie strony sporu sięgały po wiele argumentów demagogicznych ${ }^{65}$. Autor drugiego napisał z kolei, że w 1923 r. rząd Chjeno-Piasta wypracował kompromis w sprawie reformy rolnej, który pomimo tego, że koalicja się rozpadła, to kolejny rząd - W. Grabskiego - doprowadził do jego przyjęcia przez parlament ${ }^{66}$.

Czołowy polityk ludowy, czyli W. Witos, na kartach podręczników pojawił się w kontekście wydarzeń majowych 1926 r. Wówczas, jak można przeczytać w większości analizowanych opracowań, $z$ faktem, iż staną on na czele trzeciego w jego karierze, a drugiego w historii międzywojennej Polski rządu Chjeno-Piasta, nie mógł pogodzić się J. Piłsudski i jego zwolennicy ${ }^{67}$. Autorzy szkolnych opracowań zaznaczyli, że niechęć marszałka do polityków tworzących ten gabinet wynikała między innymi z tego, iż obarczał on ich odpowiedzialnością moralną za śmierć prezydenta G. Narutowicza, partyjniactwo oraz osłabienie pozycji Polski na arenie międzynarodowej ${ }^{68}$.

Warto zwrócić uwagę, iż w części opracowań podkreślono, iż po trzech dniach walk między oddziałami, które opowiedziały się za J. Piłsudskim, a tymi, które pozostały wierne rządowi, premier W. Witos oraz prezydent S. Wojciechowski podali się do dymisji ${ }^{69}$. Ich decyzja, jak zaznaczono, była podyktowana przewagą zamachowców oraz odpowiedzialnością za państwo, gdyż nie chcieli, aby walki w stolicy przeniosły się na resztę kraju ${ }^{70}$.

Przełom lat 20. i 30. XX w. to kolejny i zarazem ostatni okres w historii Drugiej Rzeczypospolitej, w którym na kartach podręczników została

\footnotetext{
$64 \mathrm{~W}$ pewnym stopniu brak odwołania się do wspomnianej kwestii rekompensuje jej ujęcie we wspomnianych zestawieniach tabelarycznych.

65 B. Burda, B. Halczak, R.M. Józefiak, A. Roszak, M. Szymczak, dz. cyt., s. 66.

66 J. Ustrzycki, dz. cyt., s. 60.

67 S. Roszak, J. Kłaczkow, dz. cyt., s. 96; J. Ustrzycki, dz. cyt., s. 94; Z.T. Kozłowska, I. Unger,

S.Zając, dz. cyt., s. 85 .

68 D. Stola, dz. cyt., s. 47.

69 J. Ustrzycki, dz. cyt., s. 95; Z.T. Kozłowska, I. Unger, S. Zając, dz. cyt., s. 85.

70 A. Brzozowski, G. Szczepański, dz. cyt., s. 89; D. Stola, dz. cyt., s. 47; S. Zając, dz. cyt., s. 57.
} 
odnotowana działalność ruchu ludowego. Pierwsza informacja dotyczy udziału dwóch głównych partii chłopskich w tzw. Centrolewie, który powstał w $1929 \mathrm{r}$. i był antysanacyjnym porozumieniem kilku partii, z których część, jak choćby PPS czy PSL „Wyzwolenie”, trzy lata wcześniej poparła zbrojne wystąpienie marszałka, a teraz była w zdecydowanej opozycji wobec rządów i polityki, której był on kreatorem. Niestety tylko w części podręczników wymieniono wszystkie ugrupowania, które tworzyły Centrolew ${ }^{\text {n1 }}$.

Pojedyncze opracowania podały wyniki wyborów parlamentarnych z 1928 r., w których partie chłopskie uzyskały odpowiednio w 1928 r. - PSL „Piast” - 5\%, PSL „Wyzwolenie” - 9\% oraz Stronnictwo Chłopskie - 9\% ${ }^{72}$. Ponadto, za sprawą W. Witosa, uwięzionego tuż przed rozpisanymi na 1930 r. przedterminowymi wyborami parlamentarnymi ruch ludowy pojawił się jako ofiara represyjnej polityki piłsudczyków. W tym miejscu należy podkreślić, że obok Wojciecha Korfantego, czyli lidera polskiej chadecji, W. Witos jest najczęściej wymienianym politykiem aresztowanym w 1930 r., co uniemożliwiło mu start wyborach ${ }^{73}$. Po podaniu tej informacji w podręcznikach pojawiła się adnotacja, że W. Witos na uprawomocnienie się tego wyroku nie czekał, gdyż udał się na emigrację do Czechosłowacji ${ }^{74}$. Istotne, że w tym kontekście w żadnym z opracowań nie oceniono tego jako akt tchórzostwa, tylko wręcz naturalne działanie w sytuacji, gdy samo uwięzienie go było skandalem, a wyrok został wydany na polityczne zamówienie. W tym miejscu zasygnalizujemy tylko, a w szczegółach przeanalizujemy w dalszej części, że w podręczniku Wydawnictwa Szkolnego PWn, który przygotował D. Stola, zamieszczono obszerny fragment wystąpienia W. Witosa na procesie brzeskim ${ }^{75}$. W kontekście tych wydarzeń nieliczne opracowania odnotowały wynik wyborów z 1930 r., w których większość ruchu ludowego występująca pod szyldem Centrolewu uzyskała poparcie na poziomie $13 \%{ }^{76}$. Są jednak od tej reguły wyjątki, jak choćby podręcznik Janusza

71 Do tego grona należą: B. Burda, B. Halczak, R.M. Józefiak, A. Roszak, M. Szymczak, dz. cyt., s. 82; S. Roszak, J. Kłaczkow, dz. cyt., s. 100.

72 D. Stola, dz. cyt., s. 48.

73 A. Brzozowski, G. Szczepański, dz. cyt., s. 92; S.Zając, dz. cyt., s. 59; J. Ustrzycki, dz. cyt., s. 97; D. Stola, dz. cyt., s. 48; S. Roszak, J. Kłaczkow, dz. cyt., s. 100.

74 R. Dolecki, K. Gutowski, J. Smoleński, dz. cyt., s. III; D. Stola, dz. cyt., s. 48. Nie wszyscy autorzy podali, że była to dokładnie Czechosłowacja, a jedynie, że „udał się na emigrację” (B. Burda, B. Halczak, R.M. Józefiak, A. Roszak, M.Szymczak, dz. cyt., s. 82).

75 D. Stola, dz. cyt., s. 48.

76 Tamże. 
Ustrzyckiego, z którego uczniowie mogą się dowiedzieć, że w 1930 r. Klub Parlamentarny Posłów i Senatorów Chłopskich liczył dokładnie 48 osób ${ }^{77}$.

Ze wspomnianym okresem przełomu lat 20. i 30. wiąże się jedna z najważniejszych dat $\mathrm{w}$ dziejach ruchu ludowego w międzywojennej Polsce, czyli jego zjednoczenie w 193I r ${ }^{78}$ Tu zwracają uwagę opisy okoliczności, a przede wszystkim powodów, które legły u podłoża decyzji, w wyniku której z połączenia PSL „Piast” i „Wyzwolenie” oraz Stronnictwa Chłopskiego powstało Stronnictwo Ludowe. I tak dla autorów podręcznika wydanego przez WSip istotne było podkreślenie, że po rozpadzie Centrolewu wymienione partie chłopskie zjednoczyły się, aby doprowadzić do powtórnej demokratyzacji państwa i skutecznie walczyć z sanacją, a następnie walczyć o reformę rolną na lepszych warunkach dla chłopów. W efekcie Stronnictwo Ludowe, jak zaznaczyli, rozwijało się bardzo szybko i w 1933 r. liczyło już 120 tys. członków.

Analizowany wątek w interesujący sposób opisali także autorzy podręcznika wydanego przez Operon, którzy podkreślili, że ugrupowania ludowe stanowiły, po obozie narodowo-demokratycznym, drugą poważną siłę polityczną w sanacyjnej Polsce. Podkreślili również, że w latach 30. $\mathrm{XX}$ w. przezwyciężone zostały podziały w ruchu ludowym, czego efektem było analizowane tu połączenie trzech partii i powstanie Stronnictwa Ludowego. Narrację w tej kwestii zamyka informacja o tym, że ludowcy organizowali antyrządowe wystąpienia chłopów pod hasłem przywrócenia swobód demokratycznych, ale nie udało im się jednak w ich wyniku zagrozić stabilności systemu sanacyjnego ${ }^{79}$. Koreluje z tym zamieszczony w drugim podręczniku wydanym przez Operon fragment wspomnień W. Witosa, w którym scharakteryzował on sytuację na wsi w 1933 r., pisząc:

Nędza na wsi przechodzi wszelkie granice. Przednówek rozpoczął się jeszcze w miesiącach zimowych. Ludzie oszczędzają soli, gotują kartofle kilkakrotnie w tej samej posolonej wodzie. [...] Przestano sprowadzać lekarzy do chorych i kupować lekarstwa, spuszczając się na opatrzność boską. Coraz mniej posyłają dzieci do szkoły, książka i gazeta staje się unikatem na wsi. Egzekutorzy chodzą po wsi [...], starając się [...] ściągnąć zalegle podatki i wysokie kary. Bardzo często zabierają poduszkę spod głowy lub ostatnią krowę ${ }^{80}$.

77 J. Ustrzycki, dz. cyt., s. 98.

78 A. Brzozowski, G. Szczepański, dz. cyt., s. 94; J. Ustrzycki, dz. cyt., s. 98; Z.T. Kozłowska, I. Unger, S.Zając, dz. cyt., s. 88; S. Roszak, J. Kłaczkow, dz. cyt., s. Ior.

79 B. Burda, B. Halczak, R.M. Józefiak, A. Roszak, M. Szymczak, dz. cyt., s. 85.

80 J. Ustrzycki, dz. cyt., s. ıı. Por.: A. Brzozowski, G. Szczepański, dz. cyt., s. 94. 
W jednym opracowaniu odnotowano, że kierownictwo Stronnictwa Ludowego nieufnie przyjęło powstanie Obozu Zjednoczenia Narodowego w 1937 r., żądając amnestii dla więźniów politycznych i emigrantów. A gdy postulaty te nie zostały spełnione, zorganizowali wielki strajk chłopski, który władze krwawo stłumiły, co dodatkowo zaostrzyło sytuację w kraju ${ }^{81}$. W jednym opracowaniu wymieniono W. Witosa jako jednego z założycieli Front Morges, który powstał w Szwajcarii w $1936 \mathrm{r}^{82}$, a w innym podano również, że był nawet kandydatem tej formacji na premiera ${ }^{83}$.

Narracja historyczna to najważniejsza część podręcznika szkolnego. Jednak tym, co odróżnia ten rodzaj opracowań od większości podręczników akademickich do historii, że o klasycznych monografiach i syntezach nie wspomnę, jest bogata obudowa dydaktyczna, której znaczenie zostało zasygnalizowane w pierwszej części artykułu. Jednym z jej najważniejszych elementów jest ikonografia, która na przestrzeni ostatnich kilkudziesięciu lat, głównie za sprawą rosnących możliwości technicznych, vide rozwój oprogramowania komputerowego, a ostatnio związanej z nim rewolucji internetowej, w sposób znaczący zmieniła oblicze książek szkolnych. Niestety w odniesieniu do takiego zagadnienia jak ruch ludowy i jego znaczenie w międzywojennej Polsce trudno jest tu mówić o jakimkolwiek przełomie. Wynika to z faktu, iż autorzy wykorzystali praktycznie tylko fotografie portretowe, de facto dwóch liderów ruchu ludowego, tj. W. Witosa, którego zdjęcie jest $\mathrm{w}$ sześciu z ośmiu analizowanych podręczników ${ }^{84}$, oraz M. Rataja, którego fotografię uczniowie mogli zobaczyć w kilku opracowaniach $^{85}$. Ponadto, w jednym podręczniku - zdjęcie przedstawiające rząd $\mathrm{W}$. Witosa z maja $1926 \mathrm{r}^{86} \mathrm{~W}$ innym proklamowanie strajku chłopskiego w Dubiecku w 1937 r. $^{87}$

81 Z.T. Kozłowska, I. Unger, S.Zając, dz. cyt., s. 91 .

82 J. Ustrzycki, dz. cyt., s. II4.

83 R. Dolecki, K. Gutowski, J. Smoleński, dz. cyt., s. II 4.

84 A. Brzozowski, G. Szczepański, dz. cyt., s. 38; Z.T. Kozłowska, I. Unger, S. Zając, dz. cyt., s. 56; D. Stola, dz. cyt., s. 17, 57; R. Dolecki, K. Gutowski, J. Smoleński, dz. cyt., s. I07; S. Roszak, J. Kłaczkow, dz. cyt., s. 88; S.Zając, dz. cyt., s. 55.

85 R. Dolecki, K. Gutowski, J. Smoleński, dz. cyt., s. 48; B. Burda, B. Halczak, R.M. Józefiak, A. Roszak, M. Szymczak, dz. cyt., s. 8I.

86 R. Dolecki, K. Gutowski, J. Smoleński, dz. cyt., s. 107.

87 S.Zając, dz. cyt., s. 6o. W podpisie pod zdjęciem uczniowie mogli przeczytać, że chłopi protestowali przeciwko nadużyciom władzy przez obóz sanacyjny, a przybrał formę wstrzymywania dostaw do miast. Ponadto autorzy napisali, że ogarnął on znaczną część Małopolski i wywołał również konflikty między samymi chłopami, a interwencje policji spowodowały śmierć 40 osób. Należy także podkreślić, że pod opisem znalazło się także, 
Kolejny element obudowy dydaktycznej podręczników stanowią teksty źródłowe. W odniesieniu do tytułowej kwestii autor artykułu doliczył się w ośmiu analizowanych podręcznikach pięciu tego rodzaju materiałów, które zalecono młodzieży do lektury. Znamienne, że wszystkie one są cytatami z W. Witosa. Dwa z nich przywołaliśmy już wyżej. Dlatego teraz przyszedł czas na trzy pozostałe. Pierwszy z nich pierwotnie ukazał się w Paryżu w połowie lat 6o. ubiegłego wieku, ale do dziś stanowi jedno z ważniejszych świadectw źródłowych do dziejów Polski pierwszej połowy $\mathrm{xx}$ w. z gatunku literatury dokumentu osobistego. Wspomniany fragment odnosi się do otwarcia obrad pierwszego sejmu w historii międzywojennej Polski. W związku z tym, że nie jest on zbyt długi, a do tego został zestawiony $\mathrm{z}$ fragmentem mowy J. Piłsudskiego wygłoszonej podczas uroczystości z tym związanych, pozwolę go sobie tu w całości przytoczyć.

$\mathrm{Na}$ otwarcie Sejmu oczekiwałem z niesłychaną wprost niecierpliwością. Czułem, że zbliża się dzień jeszcze w życiu moim nie widziany. Przed naszymi oczyma ma się dokonać cud, bo z jednej strony staje do życia państwowego na nowo rozebrana, podeptana, okaleczona i przez wrogie potęgi skazana na zagładę Ojczyzna, a z drugiej my, synowie ludu [...] stajemy do pracy nad jej budową, odrodzeniem. Jako wybrańcy wolnego już ludu mamy decydować o jej losie $[\ldots]^{88}$.

Drugie z przywołanych w tej części źródeł to fragment sprawozdania z zarządu PSL „Piast”, który odbył się 24 I 192 I r., a relację z niego zamieściła między innymi „Gazeta Lwowska”, której materiał zamieścili autorzy podręcznika Stentora w ramce z cyklu: $Z$ pierwszych stron gazet. W artykule zamieszczono wypowiedź W. Witosa, w której podkreślił rolę i znaczenie partii w Polsce, co dobitnie miało potwierdzać przypomnienie zebranym, że szef ich partii kieruje pracami rządu, jej członek - M. Rataj - jest wicepremierem, a wiceprezes partii Jan Dąbski przewodniczy delegacji na rozmowy pokojowe w Rydze. W. Witos mówił jednak nie tylko o sukcesach, ale i wyzwaniach, do których zaliczył zbliżający się na Górnym Śląsku plebiscyt oraz bardzo trudną sytuację ekonomiczną kraju. Po lekturze

co jest szczególnie istotne z dydaktycznego punktu widzenia, polecenie dla uczniów, których poproszono, aby spróbowali opisać nastrój panujący na ukazanej scenie.

88 Dwa wspomniane wystąpienia autor podręcznika opatrzył poleceniami, w których uczniowie mieli za zadanie: ocenić wpływ atmosfery, panującej wśród znacznej części społeczeństwa, na walkę zbrojną i odbudowę państwa oraz wyjaśnić, jakie znaczenie dla państwa i społeczeństwa miało rozpoczęcie prac przez Sejm Ustawodawczy (J. Ustrzycki, dz. cyt., s.24). 
tekstu uczniowie mieli odpowiedzieć na kilka prostych pytań, które dotyczyły jego treści ${ }^{89}$.

Wreszcie trzeci i jednocześnie najobszerniejszy z grona przywołanych tu tekstów źródłowych; dotyczący procesu brzeskiego, w którym W. Witos zasiadł na ławie oskarżonych. Zamieszczony został on w podręczniku Wydawnictwa Szkolnego PWN, który przygotował D. Stola ${ }^{90}$. Autor zaczerpnął go z wydanego w 2006 r. drugiego tomu pracy: Wielkie mowy historii. Od Lincolna do Stalina. Ograniczone ramy artykułu powodują, że nie ma możliwości przywołania go tu w całości, nad czym autor ubolewa. Przytoczenia kilku krótkich fragmentów - odmówić sobie jednak nie może.

Ja nie byłem przeciwnikiem p. Piłsudskiego - mówił podczas procesu Witos - ile przeciwnikiem jego metod i sposobów rządzenia. Uznać się jednak musiałem za zwyciężonego i usunąłem się w cień. Uważałem, że będąc zwyciężonym, jako polityk powinienem zwycięzcy pozostawić pole do pracy, będąc zdania, że nie można w Polsce robić wiecznych eksperymentów! [...] Śledziłem przez czas dłuższy robotę rządów pomajowych i musiałem przyjść do przekonania, że nawet chwilowe sukcesy nie mogą wyrównać strat, jakie w ogóle te rządy przynoszą. [...] Ale jeżeli przychodzą wybory, a wyborca nie może swobodnie spełnić swego prawa, jeżeli z urny wychodzi co innego, aniżeli wkłada wyborca, albo jeśli policjant poucza go pięścią lub kułakiem, jak należy głosować, to nic dziwnego, że ten obywatel od urny uciekał. Tuśmy więc przegrali, przegrała demokracja, ale przegrało też państwo, a przecież ono nie może zbyt często przegrywać. Nie chcemy więc, ażeby Polska budowana była na jednym człowieku, chcemy, aby budowało ją całe społeczeństwo. Jeżeli chcę, aby pracą państwową zainteresowało się szerokie społeczeństwo, to uważam, że rządy konstytucyjne i parlamentaryzm są najlepszym do tego sposobem i najlepszą $\operatorname{drogą~}^{91}$.

Do tekstu, którego fragment został przytoczony autor podręcznika sformułował trzy polecenia, na które uczniowie mieli odpowiedzieć po jego lekturze. Dotyczyły one wyjaśnienia okoliczności, w których została wygłoszona mowa W. Witosa, jego stosunku do sanacji i oceny jej rządów oraz wskazania wad rządów autorytarnych, na które zwrócił uwagę w swojej mowie.

Elementem obudowy dydaktycznej podręczników szkolnych są także bloki ćwiczeniowe i powtórzeniowe, które ich autorzy standardowo

89 A. Brzozowski, G. Szczepański, dz. cyt., s. 38.

90 D. Stola, dz. cyt., s. 48.

91 Tamże, s.50. 
umieszczają na końcu poszczególnych tematów i rozdziałów. Dla utrwalenia najważniejszych informacji w niektórych podręcznikach zamieszczone zostały, jako podsumowanie rozdziału, w interesującym nas tu zagadnieniu dotyczącym Drugiej Rzeczypospolitej lub też całego okresu międzywojennego w wymiarze nie tylko ojczystym, ale i powszechnym, zestawienia tabelaryczne lub osie czasu. I tak w odniesieniu do ruchu ludowego w Drugiej Rzeczypospolitej, co wynika z przedstawionej powyżej analizy, najczęściej pojawiają się w nich postacie W. Witosa i M. Rataja, które należy zapamiętać poprzez przypomnienie roli, jaką odegrali ${ }^{92}$. W jednym przypadku fotografią W. Witosa na osi czasu zilustrowano także proces brzeski przywódców opozycjii ${ }^{93}$.

Jako swego rodzaju ciekawostkę potraktować należy zamieszczone w dwóch podręcznikach rysunki satyryczne. W pierwszym przypadku- podręcznik Operonu - wzorowane są one na karykaturach z epoki i stanowią ilustrację najważniejszych wydarzeń politycznych okresu sanacyjnego. Jako postać centralną przedstawiają J. Piłsudskiego, który instrumentalnie traktuje innych polskich polityków, wśród których wyraźnie widoczny jest, na co wskazują między innymi charakterystyczne wąsy - W. Witos ${ }^{94}$. W drugim przypadku jest to przedruk oryginalnego rysunku, który w 1922 r. został opublikowany w satyrycznym periodyku „Mucha”. Tu centralną postacią jest już W. Witos, a rysunek zatytułowany „Niesforni tancerze”. W opisie do niego można przeczytać, że przedstawia polskich parlamentarzystów, którzy tworzą korowód, a każdy „tańczy” w inny sposób, co „Miało symbolizować brak zgody i umiejętności porozumienia na podzielonej scenie politycznej”"95.

Na zakończenie podkreślmy, że zawsze można doszukać się informacji i materiałów, które obraz ruchu ludowego na kartach szkolnych podręczników do historii mogłyby znacząco wzbogacić. Należy jednak pamiętać, że podręcznik, choć odgrywa ważną rolę w szkolnej edukacji historycznej i jak zaznaczono na wstępie, dla części osób jest pierwszą, ale ostatnią książką o historii, to jednak nie powinien być nadmierne "przeładowany” treściami, gdyż może odnieść efekt odwrotny od zamierzonego. I jeśli tylko po roku nauki w klasach pierwszych liceum i technikum w latach 20I2-2020 uczniowie zapamiętali, że ważnymi graczami na polskiej scenie politycznej były w latach dwudziestych takie partie, jak PSL „Piast” i PSL „Wyzwolenie”,

92 J. Ustrzycki, dz. cyt., s. 132.

93 D. Stola, dz. cyt., s. 57.

94 B. Burda, B. Halczak, R.M. Józefiak, A. Roszak, M. Szymczak, dz. cyt., s. 82, 87.

95 S. Roszak, J. Kłaczkow, dz. cyt., s. 89. Nota bene ten sam rysunek wykorzystany został na okładce pracy: Prosto z Wiejskiej. Sejm i Senat II Rzeczypospolitej w karykaturze i satyrze, wyboru dokonał i szkicami poprzedził A.Zakrzewski, Wrocław-Warszawa-Kraków 1990. 
a czołowymi polskimi politykami ich liderzy z W. Witosem na czele, to już będzie można mówić o pewnym sukcesie. I proszę, aby zanim ktoś uzna to za minimalizm, zadał sobie trud i spróbował odpowiedzieć na kilka prostych pytań z zakresu materiału szkolnego, przykładowo z biologii, fizyki i geografii na poziomie klasy siódmej szkoły podstawowej, a zapewniam, że nabierze pokory dla tego, co można przyswoić sobie na trwałe w toku szkolnej edukacji historycznej, gdzie wydarzenia gonią wydarzenia, a postacie nakładają się na siebie jak w książce telefonicznej. Z optymizmem możemy jednak spoglądać w przyszłość, a precyzyjnie na przyszły rok, w którym ruch ludowy będzie obchodził 90 . rocznicę zjednoczenia - gdy powstało odnotowane na kartach wszystkich podręczników Stronnictwo Ludowe. Zwracam uwagę na tę okoliczność, gdyż rocznicowe obchody zawsze przynoszą wzrost zainteresowania daną postacią lub wydarzeniem, a gdy zostaną jeszcze odpowiednio wzmocnione, o co powinni zadbać współcześni dziafacze ruchu ludowego, to wiedza wyniesiona ze szkoły zostanie wzbogacona przekazem, który współcześnie określa się mianem historii w przestrzeni publicznej. A tu ruch ludowy, pomimo pewnych problemów organizacyjnych i wizerunkowych oraz konkurencji w walce o wiejski elektorat ze strony partii rządzącej, ma poprzez liczne instytucje, pomniki, a także nazwy ulic, które noszą imiona ich międzywojennych liderów, jak choćby wspominanych wielokrotnie na kartach podręczników W. Witosa i M. Rataja - trwałą pozycję, na którą zapracował sobie już ponad I20-letnią historią.

\section{Bibliografia}

\section{Źródła drukowane}

Dziennik Ustaw Rzeczypospolitej Polskiej 2009, 2012

Prosto z Wiejskiej. Sejm i Senat II Rzeczypospolitej w karykaturze i satyrze, wyboru dokonał i szkicami poprzedził A.Zakrzewski, Wrocław-Warszawa-Kraków ı990.

\section{Podręczniki szkolne}

Brzozowski A., Szczepański G., Ku wspótczesności. Dzieje najnowsze 19I8-20o6. Podręcznik do historii dla klasy I liceum i technikum - zakrespodstawowy, Wydawnictwo Piotra Marciszuka Stentor, Warszawa 2012.

Burda B., Halczak B., Józefiak R.M., Roszak A., Szymczak M., Historia najnowsza. Podręcznik dla szkót ponadgimnazjalnych. Zakres podstawowy, Wydawnictwo Pedagogiczne Operon, Gdynia 2012.

Dolecki R., Gutowski K., Smoleński J., Po prostu historia. Zakres podstawowy. Podręcznik do liceum i technikum, Wydawnictwa Szkolne i Pedagogiczne, Warszawa 2012.

Kozłowska Z.T., Unger I., Zając S., Historia. Poznajemy przesztość. Dzieje najnowsze. Szkota ponadgimnazjalna. Zakres podstawowy, sop Oświatowiec, Toruń 2012. 
MAREK BIAtOKUR Ruch ludowy w Drugiej Rzeczypospolitej na kartach wybranych szkolnych...

Roszak S., Kłaczkow J., Poznać przesztość. Wiek XX. Podręcznik do historii dla szkót ponadgimnazjalnych. Zakres podstawowy. Klasa I, Wydawnictwo Nowa Era, Warszawa 2012.

Roszak S., Łaszkiewicz A., Śladami przesztości. Podręcznik do historii dla klasy trzeciej gimnazjum, Wydawnictwo Nowa Era, Warszawa 2011.

Stola D., Historia. Wiek XX. Podręcznik. Szkoty ponadgimnazjalne. Zakrespodstawowy, Wydawnictwo Szkolne PWN, Warszawa 2012.

Ustrzycki J., Historia. Zakres podstawowy. Podręcznik dla szkót ponadgimnazjalnych, Wydawnictwo Pedagogiczne Operon, Gdynia $20 \mathrm{I2}$.

Zając S., Teraz historia. Podręcznik dla szkoty ponadgimnazjalnej. Zakres podstawowy, sop Oświatowiec, Toruń 2012.

\section{Literatura}

Batok S., Internetowe strony historyczne w edukacji medialnej, [w:] Multimedia w edukacji historycznej i spotecznej, red. J. Rulka, B. Tarnowska, Bydgoszcz 2002.

Białokur M., Gabriel Narutowicz. Biografia, Opole 2016.

Bieniek M., Dydaktyka historii, Olsztyn 2009.

Bieniek M., Obudowa dydaktyczna polskich podręczników historii I795-1914, Olsztyn $200 \mathrm{I}$.

Bieniek M., Podręcznik szkolny historii, [w:] Wspótczesna dydaktyka historii. Zarys encyklopedyczny dla nauczycieli i studentów, red. J. Maternicki, Warszawa 2004.

Chorąży E., Konieczka-Śliwińska D., Roszak S., Edukacja historyczna w szkole. Teoria i praktyka, Warszawa 2008.

„Historia i spoteczeństwo. Dziedzictwo epok”. Edukacja historyczna w szkole ponadgimnazjalnej po 2013 roku, red. nauk. M. Fic, Katowice-Bielsko-Biała 2012.

Historia w przestrzeni publicznej, pod red. J. Wojdon, Warszawa 2018.

Jurek K., Internet w pracy nauczyciela historii, „W iadomości Historyczne” 200I, nr 4.

Maternicki J., Dydaktyka historii w Polsce 1773-1918, Warszawa 1974.

Nowak A., Prawdziwy koniec historii. Dostępny w Internecie: http://www.rp.pl/artykul/2358II. html? $\mathrm{p}=3$

Nowak M.J., Narutowicz Niewiadomski. Biografie równolegte, Warszawa 2019.

Osiński Z., Technologia informacyjna środkiem dydaktycznym wedukacji historycznej, [w:] Edukacja historycznaiobywatelskawszkolnictwieponadgimnazjalnym, red. G. Pańko,J. Wojdon, Toruń 2003.

Suchoński A., Kubis B., Gołębiowska A., Białokur M., Polski rok IgI8 w podręcznikach do nauczania historii i literaturze dokumentu osobistego, Opole 2018.

Suchoński A., Kubis B., Gołębiowska A., Białokur M., Polski rok IgIg w podręcznikach do nauczania historii i literaturze dokumentu osobistego, Opole 2019.

Walczak H., Drugi gabinet Wtadystawa Grabskiego I9 grudnia 1923 - 13 listopada 1925, [w:] Od Moraczewskiego do Sktadkowskiego. Gabinety Polski odrodzonej 1918-1939, pod red. J. Farysia, A. Wątora i H. Walczaka, Szczecin 20 ı。.

Wojdon J., Internet na lekcjach historii, „Wiadomości Historyczne” 2002, nr 2.

Zielecki A., Wprowadzenie do dydaktyki historii, Kraków 2007. 


\section{Strony internetowe}

http://www.men.gov.pl/podreczniki/wykaz_dopuszczone_listar.php

Streszczenie: Celem artykułu jest przedstawienie ruchu chłopskiego w II Rzeczypospolitej w wybranych szkolnych podręcznikach do nauczania historii w klasach pierwszych szkół ponadgimnazjalnych. Na podstawie podręczników uczniowie mogą dowiedzieć się, że ruch ludowy powstał w Galicji pod koniec XIX wieku. W II Rzeczypospolitej istniało kilka partii nazywanych Polskim Stronnictwem Ludowym. Przez wiele lat główną partią było Polskie Stronnictwo Ludowe „Piast”. Po odzyskaniu przez Polskę niepodległości w 1918 r. działacze tego ugrupowania weszli w skład kilku rządów. Tworzyli między innymi koalicyjny rząd Chjeno-Piasta w 1923. Jej głównymi politykami byli Wincenty Witos i Maciej Rataj. Drugą co do wielkości partią, o której w analizowanych podręcznikach jest dużo informacji, było Polskie Stronnictwo Ludowe „Wyzwolenie”, które powstało w I9I5 r. W porównaniu z Polskim Stronnictwem Ludowym „Piast” było partią lewicową. PSL „Wyzwolenie” poparło przewrót majowy w 1926 r., do którego autorów szybko się jednak zdystansowało i przyłączyło do opozycji. W I93I r. centroprawicowy „Piast”, centrolewicowe „Wyzwolenie” oraz lewicowe Stronnictwo Chłopskie połączyły się tworząc Stronnictwo Ludowe. Obraz ruchu ludowego na kartach podręczników szkolnych jest wielowymiarowy i pozwala uczniom poznać jego głównych przedstawicieli oraz program polityczny.

Słowa klucze: Druga Rzeczpospolita, ruch ludowy, podręczniki szkolne, edukacja historyczna

Summary: The purpose of this article is to present the peasant movement in the Second Polish Republic in contemporary school history textbooks. On the basis of textbooks, students can learn that the peasant movement arose in Galicia in the late nineteenth century. In the Second Polish Republic there were a few parties named Polish People's Party. For many years the main party was Polish Peasant party „Piast”. After Poland regained independence in 1918 , it formed a part of several governments, most notably after the Lanckorona Pact and in the Chjeno-Piast coalition. Its major politicians included Wincenty Witos and Maciej Rataj. The second largest party, about which there is a lot of information in the analyzed textbooks was Polish Peasant Party „Wyzwolenie” which was formed in I915. In comparison to Polish People's Party „Piast”, it was a left-wing party. PSL „Wyzwolenie” supported the May Coup in 1926, but soon afterwards distanced itself from Sanation and joined the opposition. In I93I it merged with several other parties forming the People's Party. In 193I it was created from the merger of three other, smaller, peasant-based parties: centre-right „Piast”, centre-left „Wyzwolenie” and left wing Peasant Party. The image of the peasant movement on the pages of school textbooks is multidimensional and allows pupils to get to know its main representatives and the political program.

Keywords: The Second Republic of Poland, the peasant movement, school textbooks, historical 